\title{
The effect of Calcitriol 1,25 (OH)2 - D3 on osteoblast-like cell proliferation du- ring in vitro cultivation
}

\author{
Muhamed KATICA ${ }^{1}$, Filiz TEPEKÖY² \\ ${ }^{1}$ University of Sarajevo, Veterinary Faculty, Department of Pathologic Physiology of Domestic Animals, Sarajevo/BOSNIA AND HERZEGOVINA \\ ${ }^{2}$ Altınbaş University, School of Medicine, Department of Histology\&Embryology, Istanbul/TURKEY
}

\author{
Key Words: \\ osteoblast -like cells \\ rat \\ calcitriol \\ in vitro cultivation \\ Received: 29.11.2019 \\ Accepted: 05.03.2020 \\ Published Online: 30.04.2020 \\ Article Code: 653000 \\ Correspondence: \\ M. KATICA \\ (muhamed.katica@vfs.unsa.ba)
}

ORCID:

M. KATICA: 0000-0002-8184-0065

F. TEPEKÖY: 0000-0003-1901-3787

\begin{abstract}
Osteoblasts are one of the leading components of the bone tissue, derived from mesenchymal stem cells (MSCs) under the influence of various local factors and growth hormones. 1,25-dihydroxyvitamin D3 (calcitriol), an active form of vitamin D, plays an important role in retaining calcium and phosphate homeostasis within the body. Since vitamin D is also known to have effects on cell proliferation, our study aimed to investigate the effects of different concentrations of calcitriol on the proliferation of in vitro cultured osteoblast-like cells from the bone marrow of 90-95 days old young adult rats of both sexes. Calcitriol was applied at six (6) different concentrations (nM): 0.1, 1, 10, 20, 40 and 60. Each concentration was tested four times, counting the cells after 24 and 48 hours. After 24 and 48 hours treatment, the most effective dose of calcitriol for cell proliferation was $0.1 \mathrm{nM}$ for both males and females. The greatest reduction in the frequency of osteoblast -like cells from both sexes after treatment of 24 and 48 hours, was a $60 \mathrm{nM}$ calcitriol concentration. Higher proliferative values of osteoblast-like cells were obtained in males compared to those obtained in females. Thus, the results of the current study reveal that calcitriol treatment induces the proliferation of osteoblast-like cells in a dose-dependent manner and this effect shows difference in cells from different genders.
\end{abstract}

\section{INTRODUCTION}

Osteoblasts originate from mesenchymal stem cells (MSCs) that later change into pre-osteoblasts under the influence of various local factors and growth hormones. These factors decide whether these cell precursors will change into osteoblastic or other cell types, such as fibroblast, fat cells or chondrocytes (1). The osteogenic differentiation of MSCs is mainly regulated by molecular components associated with embryonic skeletal development (2) and have recently been found to be achieved by interaction of key signaling pathways related to osteogenesis (3).

The proliferation and differentiation of cells of the osteoblastic lineage are controlled and guided by numerous transcription factors, growth factors and hormones $(4,5)$. The hormones are responsible for regulating calcium homeostasis and bone remodeling act as designators of osteoblast differentiation through activation of particular transcriptional regulators (6). Bone regeneration was induced by the growth factors related to the bone development through stimulation of osteogenic cell differentiation via a cell signaling cascade, eventually promoting alveolar bone regeneration (7).

Besides hormones and growth factors, the maintenance and achievement of the regular organization of bone tissue are also conducted with the contribution of vitamins and minerals. 1,25-dihydroxyvitamin D3 (calcitriol), an active form of vitamin $\mathrm{D}$, plays an important role in retaining calcium and phosphate homeostasis within the body. In addition to its function in preserving mineral composition, it has main roles in various bodily functions, including its contribution to immune system and antitumoral activities, as well as the maintenance of bone growth (8). Additionally, calcitriol has a particularly important place in bone tissue metabolism (9). The importance of Vitamin D compounds on cellular basis was also investigated and these compounds have been suggested to alter cellular proliferation through several mechanisms, most effectively via effects on cell cycle progression, apoptosis, and differentiation in highly cell-specific manners (10).

MSCs, which can be isolated from several adult tissues including bone marrow aspirations, are capable of inducing bone repair and regeneration in cell reconstructive therapies (11). Recently, a number of studies have revealed the effects of Vitamin D on the differentiation of osteoblasts and, more recently, on MSCs (12). Calcitriol has been found to be osteoinductive, and to have the capacity of promoting in vitro the differentiation of human MSCs into osteoblasts (13).

Researchers' conflicting views on the use of vitamin D3 are evident. Some prefer its use in children and adults with certain osteopathies. Others do not support its use in curation, finding it unnecessary $(14,15)$. Though the effects of calcitriol supplement on the growth of bone matrix were investigated and its increasing effects on the mineral intensity were determined (16), its participation on proliferation of osteoblast like cells needs further investigation.

Osteoblast cell cultivation allows the cells grow under controlled conditions, through which a test cell is available to us at any time and on which we can directly apply the desired concentrations, in our case of calcitriol, bypassing the digestive tract. Maniatopoulos et al. (17) cultured osteoblastlike cells in young rats during the biopsy of bone marrow stromal cells. Most of the recent in vitro studies regarding osteoblast-osteocyte interaction are invariably performed with rodent cells, mostly murine cells, which diminishes the clinical relevance of the data $(18,19)$.

The aim of the study was to determine the effect of 
different concentrations of calcitriol on the proliferation of in vitro cultured osteoblast-like cells from the bone marrow of 90-95 days old young adult rats of both sexes.

\section{MATERIALS and METHODS}

\section{Animals}

The experimental animals were treated under standard laboratory conditions, with adequate nutrition and treatment of trained staff. The study was conducted on 14 albino Wistar rats, of which 7 were males and 7 female rats, 90 to 95 days old and of an average weight of about 220-270 grams. The rats had free access to food and water and 12-hour shift of light and darkness. The air temperature was between 20 and $23^{\circ} \mathrm{C}$ with $60 \% \pm 10 \%$ air humidity. The animals were preoperatively selected so that they had a strong immune system and were free of all viral and parasitic diseases. The experimental procedures during this study did not conflict with the Law on Animal Welfare of Bosnia and Herzegovina (Official Gazette of Bosnia and Herzegovina, number 25/09).

\section{Surgical procedures}

Animals were sedated with lethal doses of Pentobarbitone at doses higher than $40 \mathrm{mg} / \mathrm{kg}$, i.m. (9). The hairy covering in the hindlimb region was removed. The operating area was disinfected with $70 \%$ isopropanol. The skin and subcutaneous tissue were removed, as well as the muscles of thigh and shin region. The next step involved extraction of the hind limbs with musculature, separation at the aceto-femoral (hip) and tarsal joints. The tops of the femurs and tibia were removed, thus making the bone marrow accessible and a 21 -gauge needle was used for extrusion of the bone marrow.

\section{Isolation and primary cell culture of bone marrow cells}

The obtained bones were washed several times with $\alpha$ - MEM medium ( $\alpha$ - minimal esential medium) to which a common antibiotic was added. Marrow plug suspension was dispersed by pipetting, filtered through $70-\mu \mathrm{m}$ mesh nylon filter, and centrifuged at $200 \times \mathrm{g}$ for $10 \mathrm{~min}$. After centrifugation, the supernatant containing thrombocytes and erythrocytes was decanted and the bone marrow cells were resuspended with 10 $\mathrm{ml} \alpha$-MEM, where the common antibiotics were

previously placed: $100 \mu \mathrm{g} / \mathrm{ml}$ Penicillin G, $50 \mu \mathrm{g} / \mathrm{ml}$ Gentamicin sulphate. The cells in the medium supplemented with $10 \%$ FBS were transferred to a plastic culture flask, (75 $\mathrm{cm}^{2}$ plastic culture flask - Falcon TM, Div. Becton Dickinson and Co.,Oxnard. Ca.), sl. 9. The prepared vials with half-closed stopper were immediately transferred to a special incubator with a temperature ambient of $37^{\circ} \mathrm{C}$, with a presence of 95\% air and 5\% CO. The cells were approximately seeded in density of $1 \mathrm{X}^{3} 0^{3}$ cell/vial, after the first preliminary microscopic examination. We constantly monitored the maturation of osteoblast-like cells under a light microscope, with magnification of $10 \mathrm{X}$ or $40 \mathrm{X}$. On the third day the medium was changed by adding $0,7 \mathrm{ml} 10 \%$ of FBS. On day six, the medium was enriched with $10 \mathrm{mM} \mathrm{Na}-\beta$-glycerophosphate ( $\beta-G P), 10-8 \mathrm{M}$ Dexamethasone (Dx) and $50 \mu \mathrm{g} / \mathrm{mL}$ ascorbic acid (17). After the sixth day, the medium was being changed every other day.

\section{Subculture of bone marrow cells}

On the day 12 the bone marrow cells of the examined rats were subcultured (I passage), by applying the conventional methods of porcine trypsin use obtained from the exocrine portion of the pancreas (17). We emptied the medium from small plastic vials and injected $1 \mathrm{ml}$ of pork trypsin, which was previously heated in a water bath at $37^{\circ} \mathrm{C}$, for $3-5$ minutes. 18 $\mathrm{ml} \propto \mathrm{MEM}$ was added into the same plastic culture flasks (75 $\mathrm{cm}^{2}$ plastic culture flask - Falcon TM, Div.Becton Dickinson and Co.,Oxnard. Ca.), and then, using a sterile pipette, after one minute of "shaking" the cells in suspension (from an old small pot), they were transferred to a prepared larger pot in which the medium was previously placed. Finally 1,8 ml FBS was added. The subcultured cells were placed back into an incubator at the temperature of $37^{\circ} \mathrm{C}, 100 \%$ relative humidity, and $5 \%$ of CO2 and $95 \%$ of pure air presence. The medium was being changed every other day, and the cultured cells constantly monitored using a light microscope. Over the next six days, the cells gradually progressed and the preconditions were made for the passage II, that is, for their preparation in suspension for the test.

\section{Calcitriol application (1,25(OH)2D3)}

Prepared cells in suspension after treatment with trypsin were transferred to a sterile plastic plate with appropriate dents (24 pieces). $1 \mathrm{ml}$ of cells in suspension were placed into every dent using an automatic pipette and two plates were filled, 48 dents. A third, separate plate with 24 dents was a control one. Calcitriol was applied (1,25(OH)2D3), (Hoffman- La Roche) at six (6) different concentrations (nM) : 0.1, 1, 10, 20, 40 and 60 . Each concentration was tested four times, counting the cells after 24 and 48 hours.

\section{Counting cells}

The cells were counted manually, using Thoma's hemocytometer, under the binocular light microscope Motic Type $102 \mathrm{M}$, with magnification 40X, according to the belowmentioned formula:

Counted cell number X 1000 X dilution factor, to obtain the number of cells in $1 \mathrm{~mm}^{3}$ in the suspension

$\left(1 \times 10^{-3} / \mathrm{ml}\right)(20)$. Most representative fields were electronically recorded using Motic Images Plus 2.0 software.

\section{Statistical analysis}

All data obtained in the study were processed and analyzed using the following methods of statistical analysis: Standard Error, Statistical Significance (T-Test), T-Test for small dependent samples.

\section{RESULTS and DISCUSSION}

The results of the current study reveal that calcitriol treatment induces the proliferation of osteoblast-like cells in a dose-dependent manner. Over the next few days of culture of osteoblast-like cells, an evident onset of osteoblast cell maturation was observed (fibroblasts targeting the osteoblastic phenotype) (Figure-1). The most effective activity on the proliferation of osteoblast-like cells, originating from both males and females, after a treatment of 24 and 48 hours, is a $0.1 \mathrm{nM}$ calcitriol concentration, which increases the number of cells tested by about $40 \%$ relative to control cells (Tables $1,2,4$ and 5). The greatest reduction in the frequency of osteoblast-like cells from males after treatment of 24 (Table-1) and 48 hours (Table-4) was a $60 \mathrm{nM}$ calcitriol concentration, which reduced the number of cells tested by $75.3 \%$ relative to controls. In females, the number of osteoblast-like cells was reduced by $93.9 \%$.

The results of our study show that slightly higher proliferative values of osteoblast-like cells were obtained in males compared to those obtained in females (Table 3 ). The test cells originating from males were partly more resistant to the maximum concentrations of calcitriol $(60 \mathrm{nM})$, compared to test cells originating from females, by $18.6 \%$ (Table 3 ). 


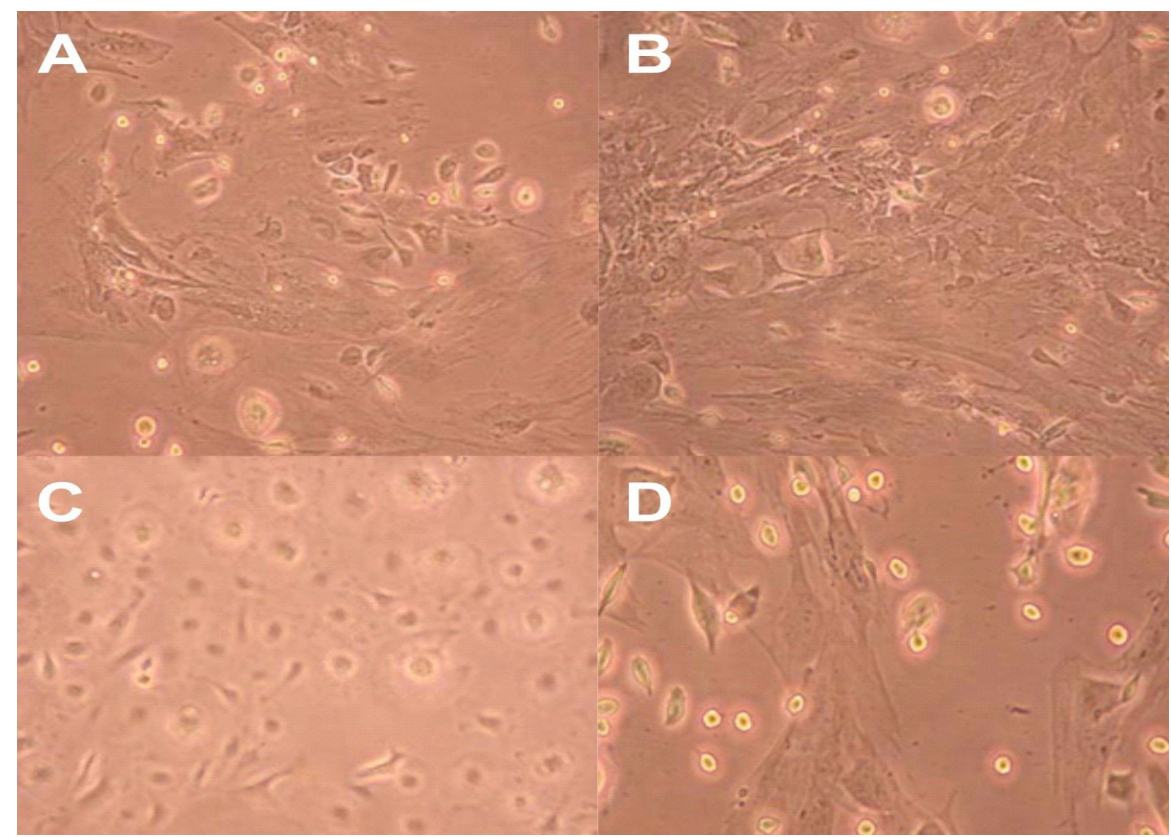

Figure 1 Microscopic photographs of test OB-like cells after the application of different concentrations of calcitriol (24 and 48 hours).

Control OB-like cells in males (A). OB-like cells in males after the application of calcitriol (24 hours) conc. 0,1 nM (B). Proliferation of OB-like cells evident (B), relative to the control OB-like cells (A). OB-like cells in males after the application of calcitriol conc.10 nM (48 hours). Obvious high numerical representation of OBs relative to the control, as well as evident destruction of certain cells (C). OB-like cells in females after the application of calcitriol conc. $20 \mathrm{nM}$ (48 hours). OBs as we 11 as corpuscles refracting light are present.

Table 1 Results obtained after application of six different concentrations of 1,25-(OH)2 - D3 Calcitriol on osteoblast-like cells of males after 24 hours

\begin{tabular}{|c|c|c|c|c|}
\hline $\begin{array}{c}\text { Concentration } \\
(\mathrm{nM})\end{array}$ & $\begin{array}{c}\text { Number of dents } \\
\text { on a plastic plate } \\
(\mathrm{n})\end{array}$ & $\begin{array}{l}\text { Arithmetic } \\
\text { mean } \\
\left(10^{3}\right)\end{array}$ & $\begin{array}{l}\text { Standard } \\
\text { deviation } \\
\text { (S.D.) }\end{array}$ & $\begin{array}{c}T-\text { Test } \\
\text { significance of } \\
\text { differences relative } \\
\text { to the control group }\end{array}$ \\
\hline 60 & 4 & 0.9 & 0.1581 & $\begin{array}{c}\mathrm{t}=15.011 \\
\text { SIGN.p }<0.01\end{array}$ \\
\hline 40 & 4 & 2.1 & 0.2345 & $\begin{array}{c}\mathrm{t}=7,229 \\
\text { SIGN.p }<0.01\end{array}$ \\
\hline 20 & 4 & 3.2 & 0.2549 & $\begin{array}{c}\mathrm{t}=1.498 \\
\text { NOT SIGN. }\end{array}$ \\
\hline 10 & 4 & 3.0 & 0.0 & $\begin{array}{c}\mathrm{t}=3.244 \\
\text { SIGN.p }<0.05\end{array}$ \\
\hline 1 & 4 & 5.5 & 0.3082 & $\begin{array}{c}\mathrm{t}=9,177 \\
\text { SIGN.p }<0.01\end{array}$ \\
\hline 0.1 & 4 & 6.0 & 0.4301 & $\begin{array}{c}t=9,449 \\
\text { SIGN.p }<0.01\end{array}$ \\
\hline Control group & 4 & 3.5 & 0.3082 & - \\
\hline
\end{tabular}

Our research is in line with that of (21), in the part related to the results obtained after calcitriol application. Wong et al. (21) in their study found increased alkaline phosphatase activity. In our case, we received increased osteoblast proliferation. According to Wlodarski, 1990 (22) and Vierecek et. al., 2002 (23), the increased activity of ALP as a major marker of osteoblast activity is necessarily accompanied by an increase in their proliferation.

It has been previously confirmed that Vitamin D affects osteoblast formation from MSCs derived from adipose tissue (24). However, there are several tissue types serving as a source for MSC such as bone marrow, adipose tissue, skin, and fetal tissues; and little is known about Vitamin D influence in osteogenic differentiation of MSCs from these alternative sources (25). The results of our study reveal the inducing effect of calcitriol on proliferation of osteoblast like cells obtained from the bone marrow.

In previous studies investigating the roles of calcitriol on bone metabolism, it was determined that calcitriol had affected bone matrix protein expression in cultured cells (26) and it was also found to modulate bone deposition process avoiding excessive and pathological mineralization (27). In addition to these studies regarding the protein expression in osteoblasts, other studies have revealed the roles of calcitriol on osteoblast growth and differentiation stimulating bone formation (28). In the current study, we focused on the effects of calcitriol on proliferation ability of osteoblast like cells, rather than their metabolic activity.

As demonstrated in previous studies, the bone extracellular matrix (ECM) includes molecules capable of defining cell differentiation through the activation of integrin subunits and providing signals that will successfully initiate and sustain cell adhesion, growth, proliferation and migration processes $(29,30)$. For proliferation, commitment, and differentiation of MSCs, cell adhesion to the substrate is also a critical process (31). It was previously shown that the use of titanium substrates and Vitamin D had an additive effect in regulating 
Table 2 Results obtained after application of six different concentrations of 1,25-(OH)2 - D3 Calcitriol on osteoblast-like cells of females after 24 hours

\begin{tabular}{|c|c|c|c|c|}
\hline $\begin{array}{l}\text { Concentration } \\
\qquad(\mathrm{nM})\end{array}$ & $\begin{array}{c}\text { Number of dents } \\
\text { on a plastic plate } \\
(\mathrm{n})\end{array}$ & $\begin{array}{c}\text { Arithmetic } \\
\text { mean } \\
\left(10^{3}\right)\end{array}$ & $\begin{array}{l}\text { Standard } \\
\text { deviation } \\
\text { (S.D.) }\end{array}$ & $\begin{array}{c}\mathrm{T}-\mathrm{Test} \\
\text { significance of } \\
\text { differences relative to } \\
\text { the control group }\end{array}$ \\
\hline 60 & 4 & 0.2 & 0.1581 & $\begin{array}{c}\mathrm{t}=35,796 \\
\text { SIGN.p }<0.01\end{array}$ \\
\hline 40 & 4 & 2.3 & 0.1225 & $\begin{array}{c}\mathrm{t}=14,144 \\
\text { SIGN.p }<0.01\end{array}$ \\
\hline 20 & 4 & 3.4 & 0.1732 & $\begin{array}{c}\mathrm{t}=1.069 \\
\text { NOT SIGN. }\end{array}$ \\
\hline 10 & 4 & 3.2 & 0.2739 & $\begin{array}{c}\mathrm{t}=0.707 \\
\text { NOT SIGN. }\end{array}$ \\
\hline 1 & 4 & 5.0 & 0.3240 & $\begin{array}{c}\mathrm{t}=10.251 \\
\text { SIGN.p }<0.01\end{array}$ \\
\hline 0.1 & 4 & 5.3 & 0.0829 & $\begin{array}{c}\mathrm{t}=36,248 \\
\text { SIGN.p }<0.01\end{array}$ \\
\hline Control group & 4 & 3.3 & 0.0707 & - \\
\hline
\end{tabular}

Table 3 Significance of differences in mean values between males and females, T-test, after application of 1,25-(OH)2- D3 calcitriol, after 24 hours

\begin{tabular}{lll}
\hline $\begin{array}{c}\text { Concentration } \\
(\mathrm{nM}) \\
1,25(\mathrm{OH})_{2}-\mathrm{D}_{3}\end{array}$ & $\begin{array}{c}\text { Significance of differences in mean values } \\
\text { between males and females, T-Test }\end{array}$ \\
\hline 60 & $\mathrm{t}=6.261$ & SIGN.p $<0,01$ \\
40 & $\mathrm{t}=1.5119$ & NOT SIGN. \\
20 & $\mathrm{t}=1.298$ & NOT SIGN. \\
10 & $\mathrm{t}=1.461$ & NOT SIGN. \\
1 & $\mathrm{t}=2.236$ & NOT SIGN. \\
0.1 & $\mathrm{t}=3.378$ & SIGN.p $<0,05$ \\
\hline Control group & $\mathrm{t}=1.265$ & NOT SIGN. \\
\hline
\end{tabular}

Table 4 Results obtained after the application of six different concentrations of 1,25-(OH)2 - D3 - calcitriol on osteoblast-like cells in males after 48 hours

\begin{tabular}{|c|c|c|c|c|}
\hline $\begin{array}{l}\text { Concentration } \\
(\mathrm{nM})\end{array}$ & $\begin{array}{c}\text { Number of dents } \\
\text { on a plastic plate } \\
(\mathrm{n})\end{array}$ & $\begin{array}{c}\text { Arithmetic } \\
\text { mean } \\
\left(10^{3}\right)\end{array}$ & $\begin{array}{l}\text { Standard } \\
\text { deviation } \\
\text { (S.D.) }\end{array}$ & $\begin{array}{c}T-T e s t \\
\text { significance of } \\
\text { differences relative } \\
\text { to the control } \\
\text { group }\end{array}$ \\
\hline 60 & 4 & 0.8 & 0.1275 & $\begin{array}{c}\mathrm{t}=13.655 \\
\mathrm{SIGN} \cdot \mathrm{p}<0.01\end{array}$ \\
\hline 40 & 4 & 2.1 & 0.1871 & $\begin{array}{c}\mathrm{t}=7,667 \\
\text { SIGN.p }<0.01\end{array}$ \\
\hline 20 & 4 & 3.2 & 0.1785 & $\begin{array}{c}\mathrm{t}=1.046 \\
\text { NOT SIGN. }\end{array}$ \\
\hline 10 & 4 & 3.5 & 0.3536 & $\begin{array}{c}\mathrm{t}=0.707 \\
\text { NOT SIGN. }\end{array}$ \\
\hline 1 & 4 & 5.1 & 0.0707 & $\begin{array}{c}\mathrm{t}=11.662 \\
\text { SIGN.p }<0.01\end{array}$ \\
\hline 0.1 & 4 & 5.5 & 0.2449 & $\begin{array}{c}\mathrm{t}=11.225 \\
\text { SIGN.p }<0.01\end{array}$ \\
\hline Control group & 4 & 3.4 & 0.2828 & - \\
\hline
\end{tabular}


Table 5 Results obtained after the application of six different concentrations of 1,25-(OH)2 - D3 - calcitriol on osteoblast-like cells in females after 48 hours

\begin{tabular}{|c|c|c|c|c|}
\hline $\begin{array}{l}\text { Concentration } \\
(\mathrm{nM})\end{array}$ & $\begin{array}{c}\text { Number of dents } \\
\text { on a plastic plate } \\
(\mathbf{n})\end{array}$ & $\begin{array}{c}\text { Arithmetic } \\
\text { mean } \\
(103)\end{array}$ & $\begin{array}{l}\text { Standard } \\
\text { deviation } \\
\text { (S.D.) }\end{array}$ & $\begin{array}{c}T-\text { Test } \\
\text { significance of } \\
\text { differences relative } \\
\text { to the control } \\
\text { group }\end{array}$ \\
\hline 60 & 4 & 0.2 & 0.1871 & $\begin{array}{c}\mathrm{t}=9.61 \\
\text { SIGN.p }<0.01\end{array}$ \\
\hline 40 & 4 & 2.6 & 0.4062 & $\begin{array}{c}\mathrm{t}=1.183 \\
\text { NOT SIGN. }\end{array}$ \\
\hline 20 & 4 & 3.4 & 0.2121 & $\begin{array}{c}\mathrm{t}=0.338 \\
\text { NOT SIGN. }\end{array}$ \\
\hline 10 & 4 & 3.2 & 0.0 & $\begin{array}{c}\mathrm{t}=0.465 \\
\text { NOT SIGN. }\end{array}$ \\
\hline 1 & 4 & 5.0 & 0.561 & $\begin{array}{c}\mathrm{t}=4.808 \\
\text { SIGN.p }<0.05\end{array}$ \\
\hline 0.1 & 4 & 5.3 & 0.200 & $\begin{array}{c}\mathrm{t}=8.433 \\
\text { SIGN.p }<0.001\end{array}$ \\
\hline Control group & 4 & 3.3 & 0.4301 & - \\
\hline
\end{tabular}

Table 6 Significance of differences in mean values between males and females, T-test, after the application of 1,25-(OH)2 - D3 - calcitriol, after 48 hours

\begin{tabular}{ccl}
\hline $\begin{array}{c}\text { Concentration }(\mathrm{nM}) \\
1,25(\mathrm{OH})_{2}-\mathrm{D}_{3}\end{array}$ & $\begin{array}{r}\text { Significance of differences in mean values } \\
\text { between males }\end{array}$ \\
\hline 60 & $\mathrm{t}=2.650$ & NOT females, T-Test \\
40 & $\mathrm{t}=2.236$ & NOT SIGN. \\
20 & $\mathrm{t}=1.262$ & NOT SIGN. \\
10 & $\mathrm{t}=1.697$ & NOT SIGN. \\
1 & $\mathrm{t}=0.172$ & NOT SIGN. \\
0.1 & $\mathrm{t}=1.265$ & NOT SIGN. \\
\hline Control group & $\mathrm{t}=0.188$ & NOT SIGN. \\
\hline
\end{tabular}

Table 7 Results of testing the significance of differences after 48 hours and 24 hours using T-Test (males)

\begin{tabular}{cccc}
\hline $\begin{array}{c}\text { Concentration } \\
(\mathrm{nM})\end{array}$ & $\begin{array}{c}\text { Average difference } \\
\mathrm{d}\end{array}$ & T-Test \\
\hline 60 & -0.1 & $\mathrm{t}=0.489$ & NOT SIGN. \\
40 & 0.0 & $\mathrm{t}=0.0$ & NOT SIGN. \\
20 & 0.025 & $\mathrm{t}=0.077$ & NOT SIGN. \\
10 & 0.5 & $\mathrm{t}=2.451$ & SIGN.p $<0,10$ \\
1 & -0.4 & $\mathrm{t}=2.771$ & SIGN.p $<0,10$ \\
0.1 & -0.5 & $\mathrm{t}=1.715$ & NOT SIGN. \\
\hline \multirow{3}{*}{ Control group } & -0.1 & $\mathrm{t}=1.091$ & NOT SIGN. \\
\hline
\end{tabular}


Table 8 Results of testing the significance of differences after 48 hours and 24 hours using T-Test (females)

\begin{tabular}{cccc}
\hline $\begin{array}{c}\text { Concentration } \\
(\mathrm{nM})\end{array}$ & $\begin{array}{c}\text { Average difference } \\
\mathrm{d}\end{array}$ & & T-Test \\
\hline 60 & 0.0 & $\mathrm{t}=0.0$ & NOT SIGN. \\
40 & 0.35 & $\mathrm{t}=1.578$ & NOT SIGN. \\
20 & 0.0 & $\mathrm{t}=0.0$ & NOT SIGN. \\
10 & 0.0 & $\mathrm{t}=0.0$ & NOT SIGN. \\
1 & 0.0 & $\mathrm{t}=0.0$ & NOT SIGN. \\
0.1 & 0.025 & $\mathrm{t}=0.181$ & NOT SIGN. \\
\hline Cont & 0.0 & $\mathrm{t}=0.0$ & NOT SIGN. \\
\hline
\end{tabular}

the integrin expression of human osteoblast-like cells, promoting the cell adhesion process (32). Vitamin D was also found to be related to osteogenic differentiation of MSCs through the activation of cell adhesion molecules (33). Thus, increased proliferation rate of osteoblast-like cells in our study by addition of calcitriol, might also be related to elevated levels of cell adhesion molecules.

Conditions such as osteoporosis, osteoarthritis, and spinal disorders were observed in females in a greater extent than males (34). The difference in rate of such diseases between females and males has been considered to be related to the difference in levels of circulating sex hormones: estrogen and testosterone (35). However, currently a novel perspective has emerged, suggesting that the differences in bone properties, including morphology and size are caused by the genetic differences in male and female cells, which contribute to sexual dimorphism between males and females (36). Sex-dependent effect of calcitriol on rat osteoblasts grown in titanium implants was also discovered previously, showing possible sex-specific effects of calcitriol on osseointegration of titanium implants (37). In recent studies it was demonstrated that different culture conditions affected the expression of proteins related to osteoblast cell function and organic components of the bone matrix in a sex-dependent manner (38). As demonstrated previously, female and male osteoblasts display differences in average basal characteristics on tissue culture polystyrene, with female cells having higher cellular alkaline phosphatase activity and levels of osteocalcin, as well as higher concentration of both forms of Transforming Growth Factor Beta 1 (TGF- $\beta 1$ ) in their conditioned media compared to male cells. In contrast, male cells were found to have greater basal levels of osteoprotegerin production (38). After the evaluation, E2 treatment was shown to be related to reduced cell number only in female cells (38). In the current study, it was revealed that osteoblast-like cells obtained from males displayed a higher proliferation rate compared to those obtained from females, suggesting that calcitriol treatment might also affect osteoblast-like cell proliferation in a sex-dependent manner.

It is possible to grow primary culture of osteoblast-like cells taken from the bone marrow of young adult Wistar rats, 90-95 days old. Calcitriol has been found to improve the proliferation of osteoblast-like cells during the application of at least a concentration of $0.1 \mathrm{nM}$. It was revealed that osteoblast-like cells obtained from males displayed a higher proliferation rate compared to those obtained from females, suggesting that calcitriol treatment might also affect osteoblastlike cell proliferation in a sex-dependent manner. A better understanding of the biology of osteoblasts is a prerequisite for better curation of diseased calcified tissues, as those are permanently exposed to numerous diseases and lesions of different traumatic, developmental and postoperative resection etiologies.

\section{REFERENCES}

1. Lagumdžija A., The effects of some peptide hormones on osteoblast-like cells- with specific fokus on pxitocin and vasopresin. Doctoral thesis. The Endocrine and Diabetes Unit Department Institutet, Sweden, 2005.

2. Olsen BR., Reginato AM, Wang W. Bone development. Annu Rev Cell Dev Biol. 2000; 16: 191-220.

3. Cui J, Zhang W, Huang E, Wang J, Liao J, Li R., et al. Bmp9induced osteoblastic differentiation requires functional notch signaling in mesenchymal stem cells. Lab Invest. 2019; 99(1): 58-71.

4. Komori T. Regulation of osteoblast differentiation by transcription factors. J Cell Biochem. 2006; 99: 1233-39.

5. Katica M. Effects of vitamin D3 and calcium on the establishment of primary osteoblast culture. Master's thesis. University of Sarajevo, Faculty of Sciences. Bosnia and Herzegovina, 2007.

6. Arumugam B, Vishal M, Shreya S, Malavika D, Rajpriya V, He Z, et al. Parathyroid hormone-stimulation of runx 2 during osteoblast differentiation via the regulation of lnc-supt $3 \mathrm{~h}-1: 16$ (runx2-as1:32) and mir-6797-5p. Biochimie. 2019; 158(10): 4352.

7. Anusaksathien O \& Giannobile WV. Growth factor delivery to re-engineer periodontal tissues. Curr Pharm Biotechnol. 2002; 3(2): 129-139.

8. Minghetti PP \& Norman AW. 1,25(oh)2-vitamin d3 receptors: Gene regulation and genetic circuitry. FASEB J. 1988; 2(15): 3043-53.

9. Ćupić V, Muminović M, Kobal S, Velev R. Pharmacology for students of faculties of veterinary medicine, $2^{\text {nd }}$ ed. Belgrade: Naučna, KMD; 2014. p.141-146; 429-432.

10. Nagpal S, Na S, Rathnachalam R. Noncalcemic actions of vitamin d receptor ligands. Endocr Rev. 2005; 26(5): 662-67.

11. Chiu LH, Lai WF, Chang SF, Wong CC, Fan CY, Fang $\mathrm{CL}$, et al. The effect of type ii collagen on msc osteogenic 
differentiation and bone defect repair. Biomaterials. 2014; 35(9): 2680-91.

12. Posa F, Di Benedetto A, Cavalcanti-Adam EA, Colaianni G, Porro C, Trotta T. Vitamin d promotes msc osteogenic differentiation stimulating cell adhesion and alphavbeta3 expression. Stem Cells Int. 2018a; 6958713: 1-9.

13. Liu P, Oyajobi BO, Russell RG, Scutt A. Regulation of osteogenic differentiation of human bone marrow stromal cells: Interaction between transforming growth factor-beta and 1,25(oh)(2) vitamin d(3) in vitro. Calcif Tissue Int. 1999; 65: $173-80$.

14. Bolland MJ \& Grey A. A case study of discordant overlapping meta-analyses: Vitamin d supplements and fracture. PLoS One. 2014; 9(12): e115934.

15. Macdonald HM, Reid IR, Gamble GD, Fraser WD, Tang JC, Wood AD. 25-hydroxyvitamin d threshold for the effects of vitamin d supplements on bone density: Secondary analysis of a randomized controlled trial. J Bone Miner Res. 2018; 33(8): 1464-69.

16. Reid IR, Bolland MJ, Grey A. Effects of vitamin d supplements on bone mineral density: A systematic review and meta-analysis. Lancet. 2014; 383: 146-55.

17. Maniatopoulos C, Sodek J, Melcher AH. Bone formation in vitro by stromal cells obtained from bone marrow of young adult rats. Cell Tissue Res. 1988; 254(2): 317-30.

18. Paine A, Woeller CF, Zhang H, de la Luz Garcia-Hernandez M, Huertas N, Xing L, et al. Thy1 is a positive regulator of osteoblast differentiation and modulates bone homeostasis in obese mice. FASEB J. 2018.; 32(6): 3174-83.

19. Buettmann EG, McKenzie JA, Migotsky N, Sykes DA, Hu $\mathrm{P}$, Yoneda S, et al. Vegfa from early osteoblast lineage cells (osterix + ) is required in mice for fracture healing. J Bone Miner Res. 2019; 34(1): 1690-706.

20. Davis JM. Basic cell culture - a practical approach. $1^{\text {st }} \mathrm{ed}$. Oxford University, Oxford: IRL Press; 1996. p. 80-90.

21. Wong GL, Luben RA, Cohn DV. 1,25-dihydroxycholecalciferol and parathormone: Effects on isolated osteoclast-like and osteoblast-like cells. Science, 1977; 197: 663-65.

22. Wlodarski K H. Properties and origin of osteoblasts. Clin Orthop Relat Res. 1990; 276-93.

23. Viereck V, Siggelkow H, Tauber S, Raddatz D, Schutze $\mathrm{N}$, Hufner M. Differential regulation of cbfa1/runx2 and osteocalcin gene expression by vitamin-d3, dexamethasone, and local growth factors in primary human osteoblasts. J Cell Biochem. 2002; 86: 348-56.

24. Logovskaya LV, Bukharova TB, Volkov AV, Vikhrova EB, Makhnach OV, Goldshtein DV. Induction of osteogenic differentiation of multipotent mesenchymal stromal cells from human adipose tissue. Bull Exp Biol Med. 2013; 155(1): 14550 .

25. Posa F, Di Benedetto A, Colaianni G, Cavalcanti-Adam EA, Brunetti G, Porro C, et al. Vitamin d effects on osteoblastic differentiation of mesenchymal stem cells from dental tissues. Stem Cells Int. 2016; 2016: 9150819.

26. Bellows CG, Reimers SM, Heersche JN. Expression of mrnas for type-i collagen, bone sialoprotein, osteocalcin, and osteopontin at different stages of osteoblastic differentiation and their regulation by 1,25 dihydroxyvitamin $\mathrm{d} 3$. Cell Tissue
Res. 1999; $297(2):$ 249-59.

27. Woeckel VJ., van der Eerden BC, Schreuders-Koedam M, Eijken M, Van Leeuwen JP. 1alpha,25-dihydroxyvitamin d3 stimulates activin a production to fine-tune osteoblast-induced mineralization. J Cell Physiol. 2013; 228(11): 2167-74.

28. van de Peppel J \& van Leeuwen JP. Vitamin d and gene networks in human osteoblasts. Front Physiol. 2014; 5: 137.

29. Schneider GB, Zaharias R, Stanford C. Osteoblast integrin adhesion and signaling regulate mineralization. J Dent Res. 2001; 80(6): 1540-4.

30. Hamidouche Z, Fromigue O, Ringe J, Haupl T, Vaudin $\mathrm{P}$, Pages JC, et al. Priming integrin alpha5 promotes human mesenchymal stromal cell osteoblast differentiation and osteogenesis. Proc Natl Acad Sci U S A. 2009; 106(44): $18587-$ 91.

31. Wang YK \& Chen CS. Cell adhesion and mechanical stimulation in the regulation of mesenchymal stem cell differentiation. J Cell Mol Med. 2013; 17(7): 823-32.

32. Raz P, Lohmann CH, Turner J, Wang L, Poythress N, Blanchard C, et al. 1alpha, 25(oh)2d3 regulation of integrin expression is substrate dependent. J Biomed Mater Res A. 2004; 71: 217-25.

33. Posa F, Di Benedetto A, Cavalcanti-Adam EA, Colaianni G, Porro C, Trotta T, et al. Vitamin d promotes msc osteogenic differentiation stimulating cell adhesion and alphavbeta3 expression. Stem Cells Int, 2018b; 6958713:1-9.

34. Tosi LL, Boyan BD, Boskey AL. Does sex matter in musculoskeletal health? The influence of sex and gender on musculoskeletal health. J Bone Joint Surg Am. 2005; 87: 1631 47.

35. Jochems C, Islander U, Erlandsson M, Engdahl C, Lagerquist M, Gjertsson I, et al. Role of endogenous and exogenous female sex hormones in arthritis and osteoporosis development in b10.Q-ncf1*/* mice with collagen-induced chronic arthritis. BMC Musculoskelet Disord. 2010; 11: 284.

36. D’Amelio P, Rossi P, Isaia G, Lollino N, Castoldi F, Girardo $\mathrm{M}$, et al. Bone mineral density and singh index predict bone mechanical properties of human femur. Connect Tissue Res. 2008; 49: 99-104.,

37. Olivares-Navarrete R, Hyzy SL, Boyan BD, Schwartz Z. Regulation of osteoblast differentiation by acid-etched and/ or grit-blasted titanium substrate topography is enhanced by $1,25(\mathrm{oh}) 2 \mathrm{~d} 3$ in a sex-dependent manner. Biomed Res Int. 2015; 2015: 365014 .

38. Berger MB, Cohen DJ, Olivares-Navarrete R, Williams JK, Cochran DL, Boyan BD, et al. Human osteoblasts exhibit sexual dimorphism in their response to estrogen on microstructured titanium surfaces. Biol Sex Differ. 2018; 9(1): 30. 